\title{
Renewable energy policies in Europe: Converging or diverging?
}

\author{
Kitzing, Lena; Mitchell, Catherine; Morthorst, Poul Erik
}

Published in:

Energy Policy

Link to article, DOI:

10.1016/j.enpol.2012.08.064

Publication date:

2012

Link back to DTU Orbit

Citation (APA):

Kitzing, L., Mitchell, C., \& Morthorst, P. E. (2012). Renewable energy policies in Europe: Converging or diverging? Energy Policy, 51, 192-201. https://doi.org/10.1016/j.enpol.2012.08.064

\section{General rights}

Copyright and moral rights for the publications made accessible in the public portal are retained by the authors and/or other copyright owners and it is a condition of accessing publications that users recognise and abide by the legal requirements associated with these rights.

- Users may download and print one copy of any publication from the public portal for the purpose of private study or research.

- You may not further distribute the material or use it for any profit-making activity or commercial gain

- You may freely distribute the URL identifying the publication in the public portal

If you believe that this document breaches copyright please contact us providing details, and we will remove access to the work immediately and investigate your claim 


\title{
Renewable energy policies in Europe: converging or diverging?
}

\author{
Lena Kitzing $^{1, *}$, Catherine Mitchell ${ }^{2}$, Poul Erik Morthorst ${ }^{1}$ \\ ${ }^{1}$ Technical University of Denmark, Risø Campus, Energy Systems Analysis, P.O. Box 49, DK-4000 Roskilde, \\ Denmark \\ ${ }^{2}$ Energy Policy Group, University of Exeter, Cornwall Campus, Treliever Road, Penryn, TR109 EZ, United \\ Kingdom
}

Accepted Author Manuscript - article published in Energy Policy 51 (2012) 192-201, http://dx.doi.org/10.1016/j.enpol.2012.08.064

\begin{abstract}
Nations today are urgently challenged with achieving a significant increase in the deployment of renewable energies. In Europe that need has given rise to a debate about the most effective and efficient support strategy. Whilst the different interests debate whether full European harmonisation or strengthening of national support policies for electricity from renewable energy sources (RES-E) is the best way forward, individual national support schemes are rapidly evolving. This study investigates how the EU member states have applied support policy types over the last decade. By identifying predominant developments in the application of feed-in tariffs, premiums, tradeable green certificates, tax incentives, investment grants, and financing support for specific technologies (wind, biomass, PV), this study shows that Europe is currently experiencing certain tendencies towards a 'bottom-up' convergence of how national policy-makers design RES-E policy supports. While some outliers remain, the policy supports of most countries become more similar in the policy types applied (dominance of feed-in tariffs) and in their scope of implementation (differentiation for installation sizes and 'stacking' of multiple instruments). These trends in national decision-making, which show tendencies of convergence, could make an EU-driven 'top-down' harmonisation of support either dispensable or at least (depending on the agreement) less controversial.

Keywords: Renewable energy policy; Harmonisation; Europe
\end{abstract}

\section{INTRODUCTION}

A significant increase in energy production from renewable energy sources (RES) is required in Europe in order to achieve emission reductions and other targets, such as related to security of energy supply. In 2009, the member states of the European Union agreed to legally binding national targets for renewable energy in 2020 (Directive 2009/28/EC). The national targets comprise all energy sectors, meaning that they can be achieved by a combination of the use of renewable energy sources to produce electricity (RES-E), heat/cooling (RES-H) and transportation (RES-T).

In order to achieve the targeted $20 \%$ renewable energy production in Europe, significant investment in new renewable projects is required. De Jager et al. (2011) and Ragwitz et al. (2011b) estimate that the annual investment volume would have to be 60-70

\footnotetext{
*corresponding author,+45 46775188, 1kit@dtu.dk.
}

billion euros, compared to the current annual investment of 20-53 billion euros. The European energy markets currently do not trigger sufficient investment levels, even with the financial supports available from policy schemes in all member states. Due to a combination of cost of renewable technologies and achievable market returns, it is not expected that the European renewable targets for 2020 will be achieved without strengthened political support (Ragwitz et al., 2011a, p.13; Klessmann et al., 2011).

As required by the EU (Directive 2009/28/EC), every member state has elaborated its own pathway for achieving the target. These pathways were published in the form of National Renewable Energy Action Plans (NREAP) between July 2010 and January 2011 (Beurskens and Hekkenberg, 2011, p. 28). The individual EU countries apply a variety of different policy supports for renewable energy sources. Table 1 shows the most common policy types implemented in the EU.

Table 1. Major RES support strategies implemented in the EU, status: August 2011

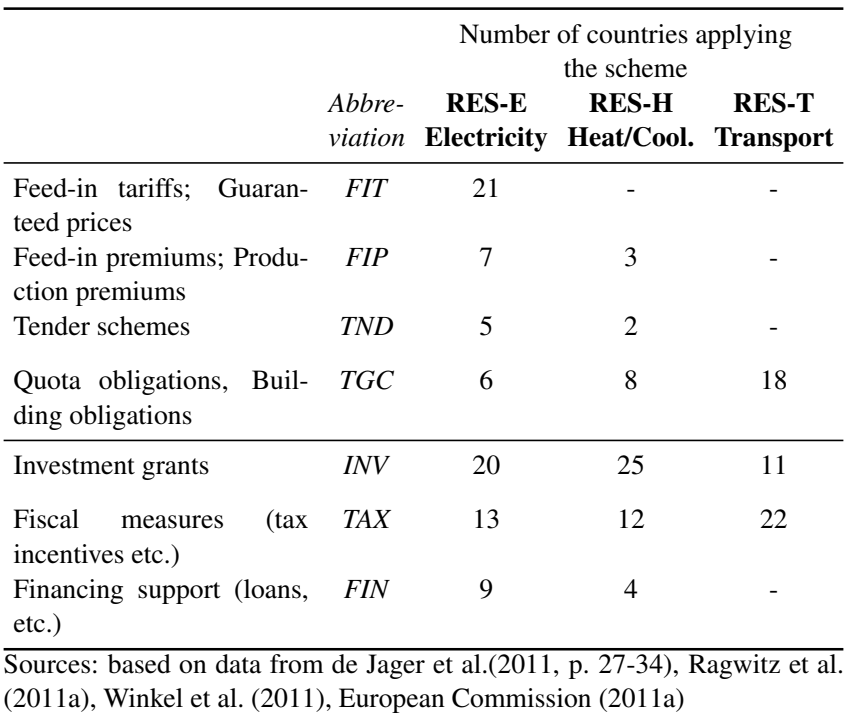

Of the three renewable energy sectors, RES-E has experienced the most diversified application of support strategies and has also 
the longest history of support. The first EU countries to introduce specific policy support for RES-E were Denmark (1979), Portugal (1988), Germany (1989) and the United Kingdom (1989/90). Today, all EU countries have implemented policy support for RESE. According to the pathways described in the NREAPs, $33.9 \%$ of the electricity consumed in the EU will be produced from renewable energy sources in 2020, with a range from $5 \%$ in Estonia to $71 \%$ in Austria. As discussed above, strengthening of financial support for RES-E is an important factor in achieving these targets.

\subsection{The research interest}

In the European Union, two general approaches are being discussed about how to organise policy support for RES-E. One approach is a fully harmonised support system, where the policy types are decided top-down and implemented alike in all member states. Prior to finalising Directive 2009/28/EC, such a harmonisation of RES-E support in Europe was concretely discussed in form of a pan-European quota obligation scheme with tradeable green certificates (TGC). However, ultimately it was not implemented in the Directive (Rowlands, 2005).

A second approach is that all EU countries have an independent choice of policy types and support schemes, so that the RES-E supports develop in a more 'bottom-up' approach. This is the current situation in Europe. Here, the European Commission is responsible for monitoring the activities of the member states and for assessing the established support policies.

More recently, regional concepts, where two or more countries cooperate on a cross-border policy scheme, have increasingly come into discussion. Some early cooperations between countries are starting to be implemented, for example between Sweden and Norway.

Whilst the debate between supporters of full EU harmonisation and supporters of full national independence of RES-E support is ongoing, the national support schemes for renewable energy are rapidly evolving. One possibility is that 'best practices' emerge along with the rapidly evolving national support schemes, and therewith policies may naturally become more similar across the individual member states. It could then be spoken of a 'bottom-up' convergence of RES-E support in Europe, whereby a 'top-down' harmonisation would become either dispensable or at least less controversial, if it coincided with the de facto 'bottom up' convergence. The European Commission sees an immediate need for a convergence of national support schemes. Referring to the EU Energy Strategy, they note that "a greater convergence of national support schemes to facilitate trade and move towards a more pan-European approach to development of renewable energy sources must be pursued" (European Commission, 2011b, p.11).

This study analyses the trends in the way EU member states are applying RES-E support policies to determine whether the national support schemes are in fact converging or diverging. In this respect, the concept of 'convergence' is understood in the notion of similarity in the decisions of policy-makers regarding the policy types to implement for RES-E, such as the choice between feed-in tariffs, tenders or quota obligations. More specifically, it is analysed if there has formed a common European understanding, or 'best practice', of what policy types to use and how to implement them (e.g. for certain technologies or installation sizes). If the choices of policy types and their scope of implementation are increasingly similar, there can be spoken of a 'convergence' of policy support for RES-E.

This is only one of several possible approaches or understandings of convergence. Ragwitz et al. (2011b), for example, argue that a gradual convergence of the key properties of policy instruments, including the use of caps and quantity control in feed-in tariffs, a technology specification in quota systems and such, can be observed (pp. 38-42). While this analysis is certainly relevant, it can be argued that the choice of policy type itself, i.e. the choice of a feed-in tariff over a quota obligation, rather than the design of its properties, is one of the most significant factors in political decision making, and one which either fosters or hinders the potential for cross-border cooperation and harmonisation. Countries that make similar decisions regarding the policy types of their support systems, e.g. those which apply quota obligation schemes, will have a broader basis for cooperation than countries with completely different support systems. The dominance of certain 'best practices' in terms of policy types could lead to more and closer cooperation, and the introduction of (partial) joint support schemes would require a less radical change. The subject of investigation in this article is therefore the choice of policy types.

\section{METHOD}

As a basis for the analysis, data on the application of policy types for RES-E support was collected from each member state of the European Union. The RES-E policy supports of all 27 countries that are now member of the European Union were analysed from their individual beginnings until the latest status in mid 2011. The focus years are 2000, 2005, 2010 and, because of the very dynamic nature of the subject, changes that occurred between 2010 and 2011 are also taken into account.

The policies were analysed on a detailed level, specific for each policy type and RES technology in each country. Data and background information were drawn from primary and secondary literature on the subject. Major sources for the analysis have been the European Commission (2011a), Haas et al. (2011), Ragwitz et al. (2011), ECN (2011), Winkel et al. (2011), Ragwitz et al. (2011), as well as policy documents from each of the 27 EU countries, mostly obtained through the website from the Federal Ministry for the Environment, Nature Conservation and Nuclear Safety in Germany, BMU (2011).

The data analysis was based on the following criteria: In order to appear in the statistics, a support scheme must be decided, implemented, in force, and open for new RES-E projects in the respective year. Tradeable Green Certificate schemes must have a functional trading platform. Announced schemes, schemes with a legal basis but without concrete implementation, and schemes without sufficient budgets were not considered. Schemes that had no funding in the respective year or were closed for new projects were excluded from the overview.

This study includes all developments until July 2011, support schemes for single technologies and/or for a limited target groups, as well as grants that make use of EU funds. As a result of these and other differences in the treatment of the underlying data, the statistics here are somewhat different from what the European Commission and others presented earlier (European Commission, 2011b, p. 10; Ragwitz et al., 2011). 
It should be noted that when a new policy scheme is implemented to replace an existing one, e.g. when a TGC replaces a FIT scheme, the existing RES-E projects often continue to be supported under the old scheme, alongside the new one - this aspect is, however, not in focus of the analysis at hand.

\section{RES-E POLICY TYPES APPLIED IN EUROPE}

Policy supports for investment in RES-E are typically based on a combination of different policy types. The policies can be differentiated according to their characteristics such as regulatory or voluntary, direct or indirect, investment-focused or generationbased, and more. Haas et al. (2011) described the categories and their differences in detail.

Here, it is sufficient to focus on policy types that are applied as part of major support schemes in EU member states. These are direct, mostly regulatory support policies. The following policy types are distinguished:

\begin{tabular}{l}
\hline Major support instruments \\
Feed-in Tariffs (FIT) \\
Feed-in Premiums (FIP) \\
Tenders (TND) \\
Quota obligations with tradeable green certificates (TGC) \\
\hline Supplementary support instruments \\
Investment grants (INV) \\
Fiscal measures (TAX) \\
Financing support (FIN) \\
\hline
\end{tabular}

In the following section, the different policy instruments are described and the criteria for their categorisations are explained.

Feed-in tariff (FIT) schemes have several elements: priority dispatch to eligible generation, long-term perspective, and guaranteed prices. The price is usually either guaranteed for a specific period (a number of years, as in Germany), or for a pre-determined amount of production (e.g. the first $10 \mathrm{TWh}$, as in Denmark for certain projects).

In most implementations of FIT (especially earlier ones), the producers of renewable electricity are exempt from market participation, and receive the guaranteed price by delivering the power to an obliged off-taker. These FITs are sometimes called 'all-inclusive' tariffs. Here, an institution (often the transmission or distribution system operator) is obliged to off-take the electricity at the guaranteed price, market the electricity and pass on the cost of the scheme, most commonly to electricity consumers, e.g. via public service obligation charges added to the electricity bill.

In some (more recent) applications, the price guarantee is granted in the form of a variable add-on to the market price. Here, a specific target price is determined as the total tariff the producer of renewable electricity should receive. The FIT is paid out as the difference between the target price and the market price. Denmark was the first country to establish such a scheme for wind power in 2000. The categorisation of target-price FIT in this analysis is in line with (amongst others) Couture et al. (2010), where target price FIT are referred to as 'sliding' premium-price FIT (p.vii). In other studies, target-price feed-in tariffs have been categorised under feed-in premiums, for example in Winkel et al. (2011). There is indeed a fine line between the two categories, as in both instruments, market price add-ons are being paid. The distinction is made here based on the existence of a target price (hence the name), which is typical for FIT in diminishing market risk for the producer, whereas FIP schemes typically only guarantee the add-on amounts and thus do not reduce the underlying market risk.

The following implementations of Feed-in tariffs currently exist in the EU:

1. Fixed feed-in tariff: One tariff is determined for each technology group and changed only with amendments to the regulation (examples are Germany, Portugal, Lithuania).

2. Time-dependent feed-in tariff: Two to three different tariffs (day / night, peak / off-peak) are pre-determined for each technology group and changed only with amendments to the regulation (examples are Spain for hydro and biomass, Hungary)

3. Indexed feed-in tariff: Tariffs depend on specific market indicators such as the exchange rate to the euro or the price of natural gas, and are therefore not certainly known at the time of investment (an example is Latvia)

4. Adjusting Feed-in tariff: Tariffs are not strictly fixed from time of installation, but amendments in the regulation may also apply for existing projects (examples are Bulgaria and Czech Republic)

5. Target-price Feed-in tariff: The tariff is guaranteed as targetprice and paid out in the form of an adjusting add-on to the market price so that the market price is topped-up (or reduced) to the guaranteed price. Those prices can be pre-determined for technology groups under the regulation or subject to projectspecific agreement e.g. through tenders (examples are Denmark and from 2012 onwards also Germany). The rationale behind using target-price Feed-in tariffs is typically to facilitate the market integration of the electricity production under FIT while still providing protection from market risk through the guaranteed target price. Target-price Feed-in tariffs that are based on negotiated prices are also referred to as Contracts for difference (CfD). Currently, the UK is in the process of establishing such a scheme, with the detailed set-up yet to be determined (for up-to-date information, see Department of Energy \& Climate Change, 2012).

Feed-in premiums (FIP) are guaranteed premiums paid out as fixed add-on to the market price. Generally, a producer of renewable electricity receives a premium per unit $(\mathrm{MWh})$ in addition to the proceeds of selling the power on the free market. As with FITs, the premiums are generally guaranteed for either a fixed period (as in Italy) or a pre-determined production (as in Denmark, for example for 12.000 full load hours).

The following implementations of the guaranteed premium currently exist in the EU:

1. Fixed Feed-in premium: A fixed premium is pre-determined by regulation for each eligible technology group, and changed only with amendments of the regulation (examples are Denmark, Spain, Estonia, Slovenia) 
2. Adjusting Feed-in premium: Tariffs are not strictly fixed for projects, but amendments to the regulations may also apply for existing projects (an example is the Czech Republic). Premiums can also be variable dependent on certain indicators, such as in Spain, where premiums vary on the basis of per-hour market prices, providing a floor and cap for the income of a producer of eligible RES-E. The rationale behind providing caps and floors is typically to protect producers from extensive risk exposure towards low market prices, while limiting the risk of over-compensation for high market prices.

It should be noted that several other studies, including Couture and Gagnon (2010), treat feed-in premiums as a subcategory of Feed-in tariffs.

Tenders (TND) are typically used in combination with another policy type. In the specific combinations, quite distinct characteristics arise for authority planning as well as for investor risk. In a tender process, the responsible authority launches calls for tenders for specific projects (or specific groups of projects) with defined amounts of capacities. Potential investors then compete to win the opportunity to develop the project by giving their bid for the required support level and several other specifications (as e.g. specific timing of the project, grid positioning, and environmental impact). The most attractive bid, determined by a low requested support level and favourable other specifications, wins the tender. There currently exist two different implementations of tender processes in the EU:

\section{Tenders for fixed Feed-in tariffs (an example is France)}

2. Tenders for target-price Feed-in tariffs (an example is Denmark)

In 1994 in Ireland (in AER I), tenders for investment grants were used. This was however discontinued due to limited success of the model, and already in the preceding bidding round AER II in the same year, the tender was re-designed to bidding for fixed feed-in tariffs. The UK also implemented a tender -the Non Fossil Fuel Obligation (NFFO) - in 1990, transferring to a TGC in 2002.

Quota obligations with Tradable Green Certificates (TGC), also called Renewable Portfolio Standards (RPS) with Renewable Energy Certificates. In TGC schemes either producers or suppliers of energy are obliged to have a specific share of renewables in their portfolio (the quota obligation). Thus, in contrast to FIT and FIP, where price levels are controlled by the policy-makers, TGC are referred to as 'quantity'-control instrument. Certificates that represent a certain production from renewables (e.g. $1 \mathrm{MWh}$ of 'green' electricity equals 1 TGC) are used to demonstrate compliance with the quota obligation to the authorities. These certificates can be freely traded on the market and a market price materialises for the certificates in each compliance period (e.g. one year). TGC schemes can be uniform or differentiated in the granting of certificates per generated unit of electricity. If the scheme is uniform, all technologies receive the same amount of certificates per generated unit of electricity (examples are Sweden, Belgium, Poland). If they are differentiated, certain technologies receive more certificates per generated unit and others less. The latter is called 'banding' of the certificates (examples are UK, Italy, Romania). In some applications, certificates can be transferred from one compliance period to the next, they are 'bankable'. This increases the stability of the certificate market and can help making the system more efficient (an example is Sweden).

Not included in the analysis are voluntary green certificate trading schemes of the type "guarantee of origin" which do not impose a quota obligation and a penalty of non-compliance.

Investment Grants (INV) are financial supports granted by governmental (and European) institutions to investors in renewable energy projects in the form of non-reimbursable payments at the construction phase of a project. Most investment grants are paid out for the construction of a project, so the amount of RES-E being generated from the project is not directly targeted. Often the payments are however subject to e.g. the successful completion and grid connection of a project and the fulfilment of certain performance standards. Most of the European countries have implemented some sort of investment grant scheme for RES-E. The grants range from $5 \%$ to more than $70 \%$ of the total investment cost.

Fiscal measures (TAX) comprise mainly direct fiscal support. Indirect tax incentives, such as eco-taxes on fossil fuels or $\mathrm{CO}_{2}$ taxes, are not specifically considered as support instrument in this analysis because it is assumed that they are implemented solely to internalise external cost. There are several direct fiscal support measures implemented in the EU:

1. Income tax reliefs are granted either as partial or full relief, directly (as for example in Belgium) or through enhanced capital allowances and other favourable depreciation rules on the investment cost (as in UK, Netherlands).

2. Electricity tax reliefs are granted in some countries where electricity generators are subject to electricity taxes (as for example in Poland and Latvia).

3. Reduced value added tax (VAT) can be applied on sales from eligible technologies (as for example in France and Portugal).

4. Net metering for own consumption can have the effect of tax relief from all taxes imposed on energy consumers, generally energy taxes and VAT. RES-E production for own consumption benefits in these cases from such tax reliefs (as for example in Denmark for small house installations).

Financing support (FIN). This category depicts a range of support instruments in the financing area. Regulation No 1828/2006 of the European Commission (2006, Article 43/1) defines such instruments within the context of repayable investments (in contrast to non-reimbursable grants) as 'financial engineering instruments'.

These can be reimbursable equity investments or provisions of venture capital by governmental institutions, but also debt financing, e.g. in form of low-interest loans to renewable projects by a governmental financial institution (such as the KfW in Germany). More recently introduced instruments are Mezzanine finance (equity/debt hybrids), equity guarantees, loan guarantees and securisation products (e.g. provision of credit default swaps), amongst others provided by the European Investment Bank (EIB). These instruments are designed to help the investors of renewable projects to access the capital market and to obtain financing at adequate 
terms, making more investments possible and therewith adding to renewable growth at low support cost.

\section{TRENDS IN THE DEVELOPMENT OF SUPPORT SYSTEMS IN EUROPE}

Some major trends in the development of national support policies for RES-E in the European Union are investigated in this section. A very obvious and general trend is the rapid development of RESE policy schemes. Most support schemes are being changed and improved on a continuous basis. Each year, new schemes are implemented and others are amended in many countries of the European Union. Three areas are investigated for trends in more detail:

1. Establishment of renewable support schemes

2. Differentiation of support schemes

3. Combinations of support schemes

The first area of investigation refers to when RES-E support policy schemes are established in the different countries, which types of policies are applied and how that develops over time. The second area refers to the extent to which the application of policy types is differentiated and specialised for certain technologies and installation sizes. The third area of investigation refers to whether and how different policy types are combined to function together in a single country.

\subsection{Establishment of renewable support schemes}

Prior to 2000, fifteen countries in the EU have provided explicit policy support for RES-E, which were also the fifteen EU member states at that time. In the following years, all other countries which are now EU member states, have introduced RES-E support schemes, so that since 2007 explicit policy support is available for RES-E in all EU countries. This comprehensive development was largely driven by a pan-European policy framework, which amongst other things included the suggestion for a target share of renewable energy already in 1997 (European Commission, 1997), and the recognising of the need for policy support for renewables in the Community guidelines for State aid for environmental protection (European Communities, 2001, p.3).

Table 2 provides an overview of how EU countries have provided RES-E policy support over the past decade.

Only a very limited number of countries strategically provided investment grants or fiscal measures as their primary support instruments. Finland was in fact the only country strategically opting for tax exemptions as major instrument for most renewable technologies until it also implemented a FIT scheme in January 2011 (subject to EC approval), after a FIT for peat in biomass plants had been in place since 2010. In other countries INV, FIN and TAX were (temporarily) the only support instruments mainly due to late or delayed implementation of other major measures, for example in Cyprus, where the in 2003 decided FIT scheme was not enacted until 2009.

\subsubsection{Major RES-E support instruments}

As of 2011, every EU country has implemented at least one of the major support instruments FIT, FIP, TND or TGC. Amongst the
Table 2. RES-E support policies in EU countries 2000-2011

\begin{tabular}{lcccc}
\hline & \multicolumn{5}{c}{$\begin{array}{c}\text { Number of countries that have } \\
\text { implemented the scheme }\end{array}$} \\
& $\mathbf{2 0 0 0}$ & $\mathbf{2 0 0 5}$ & $\mathbf{2 0 1 0}$ & $\mathbf{2 0 1 1}$ \\
\hline Provision of renewable support & 15 & 24 & 27 & 27 \\
Provision of major support schemes & 10 & 22 & 27 & 27 \\
FIT, FIP, TND or TGC & & & & \\
Provision of INV, TAX or FIN as & 4 & 2 & 1 & - \\
primary support & & & & \\
\hline Major support schemes & & & & \\
Feed-in tariffs (FIT) & 7 & 16 & 23 & 21 \\
Feed-in premiums (FIP) & - & 4 & 7 & 7 \\
Tenders (TND) & 2 & 2 & 6 & 5 \\
Quota obligations with TGC & 1 & 6 & 6 & 6 \\
\hline Supplementary support schemes & \multicolumn{4}{c}{} \\
Investment grants (INV) & 5 & 10 & 20 & 20 \\
Fiscal measures (TAX) & 9 & 10 & 12 & 13 \\
Financing support (FIN) & 4 & 4 & 9 & 9 \\
\hline
\end{tabular}

major support instruments, FIT schemes are clearly dominant. They have not only the highest share of countries implementing it (from $50 \%$ in 2000 to $85 \%$ in 2010), but also the highest growth rate in application: Between 2000 and 2010, each year almost two new countries introduced a FIT scheme on average. In the year 2011, FIT have experienced a slight 'pull-back' as the Slovak Republic and Estonia have discontinued their FIT, both to the favour of a FIP scheme remaining in place. This is discussed further in section 5.1.

Denmark was the first country to implement FIP payments in 2003 as fixed premium for new onshore wind installations. Recently, FIP schemes have come more and more into focus, and have reached a maximum of 7 implementations.

Complete re-orientation of policy schemes in a country is relatively rare. A few instances can be mentioned: In 2002, the UK switched from a tendering scheme (under the Non-fossil fuel obligation) to a TGC scheme and is currently considering updating the RES-E support as part of the energy market reform, which includes the possibility of introducing the aforementioned FIT CfDs for larger scale renewable schemes, alongside the FIT for schemes under 5 MW (see section 3). Also Italy introduced a TGC scheme in 2002 after a period of FIT support. Austria switched, after a transition phase, from a TGC scheme (which was discontinued in 2002) to a FIT.

\subsubsection{Supplementary RES-E support instruments}

Only two countries (Ireland and Slovenia) have not implemented at least one of the supplementary support schemes INV, TAX or FIN. Amongst the supplementary support instruments, investment grants are with currently 20 implementations clearly dominant. They have also the highest growth rate having increased to $400 \%$ of the implementations in 2000 . This is even a more significant increase than for FIT schemes.

Financing support (FIN) is becoming more and more significant having increased from 4 to 9 implementations. This development is of special interest in the analysis of RES-E policies from a European perspective since this support can actually rather easily be granted 
Table 3. RES-E support policies, differentiated for technologies and installation sizes, status mid 2011

\begin{tabular}{|c|c|c|c|c|c|c|c|}
\hline & \multicolumn{7}{|c|}{ Number of countries that have implemented the scheme in 2011} \\
\hline & \multicolumn{2}{|c|}{ Photovoltaics } & \multicolumn{2}{|l|}{ Biomass } & \multicolumn{2}{|c|}{ Onshore wind } & \multirow{2}{*}{$\begin{array}{l}\text { Offshore wind } \\
\text { all sizes }\end{array}$} \\
\hline & small $(<5 \mathrm{MW})$ & large & small $(<50 \mathrm{MW})$ & large & small (<20MW) & large & \\
\hline Feed-in Tariffs & 18 & 12 & 20 & 13 & 19 & 15 & 9 \\
\hline Feed-in Premiums & 4 & 4 & 6 & 4 & 5 & 5 & 3 \\
\hline Tendering scheme & 1 & 3 & 1 & 2 & 1 & 1 & 4 \\
\hline Tradable Green Cert. & 5 & 5 & 6 & 6 & 6 & 6 & 5 \\
\hline
\end{tabular}

independently from countries and national support schemes. This is further discussed below.

\subsection{Differentiation of support instruments}

From the analysis above, it becomes apparent that there are many more policy schemes implemented in the EU than there are countries. This is partly due to the differentiated implementation of policy supports, so that specific policy instruments are applied for different parts of the RES-E production. The two most apparent differentiation options are investigated below, namely the technology type and the installation size.

Table 3 shows the number of countries that have implemented the major policy types, differentiated for technologies and installation sizes. The classifications into 'large' and 'small' installation sizes are made technology-specific, taking typical sizes of PV, biomass, and wind power installations into account. For example, a size of 10MW is large for PV installations, but small for onshore wind power projects. A differentiation of offshore installations is not considered due to the generally large size of such commercial projects.

Also here, FIT schemes dominate the picture. The new aspect in the analysis relates mainly to their differentiated application. FIT schemes show a significant differentiation regarding the installation sizes: Significantly more countries apply FIT schemes for small installations than for large installations, and this is the case for all technologies. Not considering the special case of offshore wind (where most installations are large), we see a broad application of FIT schemes for small installations across all technologies, ranging from 18 countries for PV to 20 countries for biomass. Large installations are significantly less often supported with FIT schemes, ranging from 12 countries for PV to 15 countries for onshore wind. The differentiation for installation sizes is far more significant than for the technology itself.

There is a small tendency for tendering schemes to be applied to large installation sizes, especially for PV, where three countries apply TND schemes for large installations, but only one country also requires tendering rounds for (groups of) small installations. However, due to the low number of schemes implemented, no overall conclusions can be drawn. Offshore wind installations, with their typically large size, have a significantly different distribution of policy types than the other considered technologies. A higher share of the countries applies TND schemes (4 out of 17 countries that offer support for offshore wind).

\subsection{Combinations of support instruments}

After having analysed the establishment of policy schemes and their differentiation according to technologies and installation sizes, a third area of investigation becomes possible: how the differentiated policy instruments are combined.

The average number of support instruments per country is an indicator of the willingness of countries to combine several instruments in their policy support. Table 4 shows that the average number of support schemes has increased significantly from one instrument per country in 2000 to three instruments per country in 2011.

Table 4. Average number of support instruments applied per country in the EU, 2000-2011

\begin{tabular}{lcccc}
\hline & \multicolumn{4}{c}{$\begin{array}{c}\text { Number of instruments } \\
\text { applied in a country }\end{array}$} \\
& $\mathbf{2 0 0 0}$ & $\mathbf{2 0 0 5}$ & $\mathbf{2 0 1 0}$ & $\mathbf{2 0 1 1}$ \\
\hline $\begin{array}{l}\text { Average number of RES-E policy } \\
\text { instruments }\end{array}$ & 1.0 & 1.9 & 3.1 & 3.0 \\
$\begin{array}{l}\text { Average number of major support } \\
\text { instruments }\end{array}$ & 0.4 & 1.0 & 1.6 & 1.4 \\
$\begin{array}{l}\text { Average number of supplementary } \\
\text { support instruments }\end{array}$ & 0.7 & 0.9 & 1.5 & 1.6 \\
\hline
\end{tabular}

There are two general ways on how support instruments can be combined. Firstly, two or more support instruments can be implemented in parallel, so that RES-E producers may choose their preferred type of support. This is mostly the case for FIT and FIP combinations. Secondly, different instruments can be made available for specific parts of the RES-E production (e.g. TND for offshore wind, or all projects below $12 \mathrm{MW}$ are eligible for a FIT).

Table 5 shows, how the different policy instruments are combined with each other in EU member states. Only the most relevant and significant combinations are listed in the table. This analysis shows for example that of the 27 countries which have implemented a major support instrument in 2011 (see Table 2), 17 countries apply only one major instrument, eight countries apply two and the remaining two countries apply even three major instruments. Out of the 21 countries that apply FIT (see Table 2), five countries have combined them with FIP, and five others with TND.

\subsubsection{Major support instruments}

The combination of major support instruments for RES-E is a rather recent phenomenon. In 2000, no country had implemented more than one major instrument. In 2010, the number was temporarily up to 13 countries applying at least two major instruments. Two EU countries even apply three major instruments. One of them is Denmark, which provides support for onshore wind and biomass in the form of fixed FIP, support for PV and other technologies in the 
Table 5. Combinations of RES-E policy instruments implemented in EU countries 2000-2011

\begin{tabular}{lcccc}
\hline & \multicolumn{4}{c}{$\begin{array}{c}\text { Number of countries that have } \\
\text { implemented the scheme }\end{array}$} \\
& $\mathbf{2 0 0 0}$ & $\mathbf{2 0 0 5}$ & $\mathbf{2 0 1 0}$ & $\mathbf{2 0 1 1}$ \\
\hline Major support instruments & & & & \\
One major instrument applied & 10 & 18 & 14 & 17 \\
Two major instruments applied & - & 3 & 11 & 8 \\
Three major instruments applied & - & 1 & 2 & 2 \\
Combination of FIT and FIP & - & 3 & 7 & 5 \\
FIT with an added TND process & - & 2 & 6 & 5 \\
Combination of FIT with TGC & - & - & 2 & 2 \\
\hline Supplementary support instrum. & & & & \\
One supplementary instrum. applied & 9 & 10 & 13 & 12 \\
Two supplementary instrum. applied & 3 & 4 & 8 & 9 \\
Three supplementary instrum. applied & 1 & 2 & 4 & 4 \\
Combination of INV and TAX & 2 & 5 & 8 & 9 \\
Combination of INV and FIN & 2 & 2 & 6 & 6 \\
Combination of TAX and FIN & 2 & 3 & 6 & 6 \\
\hline Major and supplementary instrum. & & & & \\
Combination of FIT and INV & 2 & 6 & 16 & 15 \\
Combination of FIT and TAX & 4 & 6 & 9 & 9 \\
Combination of FIT and FIN & 2 & 4 & 8 & 8 \\
Combination of TGC and INV & - & 3 & 5 & 5 \\
Combination of TGC and TAX & - & 3 & 4 & 4 \\
Combination of TGC and FIN & - & - & 1 & 1 \\
\hline
\end{tabular}

form of fixed FIT, and support for offshore wind in the form of TND for guaranteed feed-in prices. The other country, Italy, has next to its general TGC scheme also implemented a FIT scheme for small projects (up to $1 \mathrm{MW}$ ) and a FIP scheme for solar power.

A parallel implementation is most commonly seen for FIP and FIT schemes, where FIP is the 'additional' instrument. Spain is since 2004 the most prominent example for a long-term parallel implementation of FIT and FIP. In some other countries, the two instruments are implemented in parallel for a period, before a transition is initiated. This can be seen for transitions from a FIT to FIP scheme, as in the Slovak Republic, where the FIT has been phased out in 2010 and only the FIP remains.

Most TND schemes are now tenders for guaranteed prices, which are obviously closely related to FIT schemes. In fact, most current TND schemes were introduced in addition to an already existing FIT scheme.

TGC schemes are prone to be used as sole major instrument, because the size of the certificates market is a success factor for the instrument (for example in relation to target setting, see Morthorst, 2000). However recently, TGC schemes were supplemented by FIT schemes, namely in Italy from 2008 and in the UK since April 2010. The combined use of TGC and FIT represents a shift in political decision making in the two countries, away from a support that is based on pure quantity-control (TGC) towards a more differentiated support including both quantity and price control (TGC and FIT).

\subsubsection{Supplementary support instruments}

A significant trend in the development of supplementary support instruments is the increasing number of countries who use two or even three supplementary instruments in parallel. In 2011, this reached a new maximum of 13 countries. All relevant combinations have increased over the last decade and there is no clear trend for certain combinations to become dominant.

\subsubsection{Major and supplementary support instruments}

From the analysis of combining major support instruments, it is understood that the implementation of FIP and TND is very closely related to FIT schemes. Therefore, the focus is on TGC and FIT only in the following analysis. Conclusions for FIP and TND can then be drawn from the results related to FIT schemes.

From Table 5, it becomes apparent that in absolute terms, the combination of FIT and INV is dominant, which is of course due to the dominance in the implementation of both the instruments. Relatively seen, the trend to combine a major instrument with supplementary instruments is equally significant for both FIT and TGC schemes. Currently, there is no TGC scheme where not at least one of the supplementary instruments is implemented in parallel, and there is only one country (Slovenia) where no supplementary instrument is available next to the FIT/FIP scheme. Financial support instruments (FIN) show the greatest difference in the application under a FIT or TGC scheme, respectively. They are almost solely implemented in countries that use FIT as major support instrument.

\section{DISCUSSION AND POSSIBLE FUTURE TRENDS}

The above described analysis and its results can help to draw conclusions on some trends in the development of RES-E policy supports in Europe. The results should however be interpreted carefully, as the analysed data do not represent a statistically sufficient quantity for general conclusions. Nor were policy makers' intentions and planning taken into consideration -only those policy support schemes that were finally implemented have entered the database. It might bias the conclusions regarding a convergence dependent on policy decision-making whenever the implementation of 'decided' policies was prohibited or delayed by other factors, such as bureaucratic or other processes.

\subsection{Discussion of observed developments}

There is a rapid development of RES-E policy supports. As was shown by the historical analysis, the RES-E support landscape in the European Union has changed a great deal in just one decade. It can be expected that much of the development is driven by policy makers' efforts to make their national RES-E policy support schemes more successful - that is, to make them more effective and efficient.

In that regard, many detailed studies have been conducted to assess the performance of either the policy support in one country or of a specific policy instrument in several countries (see for example Ragwitz et al., 2007; Jacobsson et al., 2009; Held et al., 2010; Ragwitz et al., 2011; Menanteau, et al., 2003, Morthorst, 2003). Many of these studies have presented policy recommendations and best practices for policy makers, which may have contributed to a pan-European understanding of which policy types to implement for the support of RES-E.

This section discusses whether the observed trends described in section 4 show characteristics of a convergence, and where there 
are exceptions from the rule. A precondition for a comprehensive development of RES-E policy support in Europe is the existence of support schemes in all countries. Since 2007, all of the 27 EU countries have implemented RES-E supports, and since 2010 all of them have provided support with at least one of the three major support instruments: FIT, FIP or TGC.

The first significant trend in the development of RES-E policy supports in the EU, shown in section 4.1, is the dominant use of price-control instruments (i.e. FIT or FIP), especially FIT. They are not only implemented in most countries, they also show the highest growth rate throughout the period. While TCG schemes experienced a small 'boom' in the early two-thousands, no new TCG scheme has been implemented after 2005. On the contrary, existing TCG schemes have lately been supplemented with FIT schemes for small installation sizes in the UK and in Italy. In mid 2011, there remain four 'outlier' countries that do not apply any form of price-control instrument. These are Belgium, Sweden, Romania and Poland.

Secondly, section 4.2 shows the differentiation of major policy types according to installation sizes. FIT are again dominant, especially for small installations. On average, there are $44 \%$ more countries applying FIT for small installations than for large ones, across all technologies. Some examples of specialised FIT for small installations are France (TND for large installations), Italy and the UK (TCG for large installations), as well as Slovenia (FIP for large installations). Other countries support only small installations of certain technologies, such as Hungary and Luxembourg. The results suggest that there has formed a common understanding amongst policy makers that price-control schemes are especially suitable for small installations. However, there are still several countries that do not differentiate their major support schemes for installation sizes, such as Germany (FIT for all sizes and technologies) or Sweden and Belgium (having implemented a single major scheme, i.e. TCG). Here, some sort of persistence seems to remain next to a common trend of convergence.

The third significant trend, shown in section 4.3, is that European countries have begun to apply multiple support instruments at the same time. This observation goes also in line with the above described trend to differentiate policy support. Countries apply now a whole range of different support policy instruments in combination (they 'stack' instruments) rather than having one major and/or supplementary instrument, which was still the norm in the year 2000. Denmark was at the forefront of applying multiple instruments and currently applies six of the seven investigated policy types. Also France, Portugal, Italy, Netherlands and Spain all apply four to five policy types in parallel, including at least two parallel major support instruments. Furthermore, certain combinations of support instruments are dominant: Especially FITs are used in combination with other major support instruments, especially FIP and TND, but also TGC in the UK and Italy. An outlier country seems to be Ireland, which currently has only one single instrument in place, namely FIT.

Based on these three trends, it can be concluded that there are certain areas, in which the national policy makers in Europe are making more and more similar decisions. This development could indicate that a bottom-up convergence is ongoing in the respect it is investigated here: Firstly, policy makers make more similar decisions in what policy types they implement, namely price-control instruments become more and more dominant. Secondly, they are also converging in how they are implementing the instruments, namely they use the instruments more differentiated and 'stacked'. Especially FITs are applied most significantly for small installation sizes. The average number of policy instruments in a country has grown from one to three parallel instruments.

This analysis has however also shown that some diverse practices are persistent. There are countries that do not apply price-control instruments at all, and some countries do not differentiate or 'stack' instruments. What is revealed here are dominant trends, not comprehensive developments that include all countries. It cannot be concluded that (even if the current trends are followed further) the development of national policy supports would eventually culminate in completely comparable policy supports. One should rather expect an incomplete alignment of policy supports through such a bottom-up development, with some 'outliers' remaining. On the other hand, a 'top-down' harmonisation cannot guarantee a full alignment either. In Europe also some top-down developments show signs of partial convergence, as can be seen in the progress on the internal gas and electricity market and the number of ongoing infringement procedures (European Commission, 2011c).

It is still to be seen whether the differentiation and 'stacking' of policy instruments actually improves the effectiveness and efficiency of RES-E policy supports in the EU. Both positive and negative effects can be induced by combining different support schemes. For example adding an FIT scheme to an existing TGC scheme can foster investment from smaller investors (see Mitchell et al., 2006), but it could also decrease the market volume for certificates, which could make the TGC scheme less efficient.

The effect of combining major and supplementary instruments should also be investigated regarding the effectiveness and efficiency. For example, combining tax incentives with major operatingsupport schemes, or combining investment grants with tendering schemes, could potentially produce severe overlapping and distorting effects, especially when not all project developers or investors can benefit from all schemes equally. It could e.g. occur that there exist restrictions for receiving grants for certain market players or that different companies have different qualifying tax bases in case of tax reliefs. Such distorting effects are not always investigated detailed enough at the time a new instrument is added to the RES-E supports in a given country.

This analysis identifies and describes trends in RES-E policy supports in Europe; it does not answer the question of what causes the observed trends. With a better understanding of the causes, it would be possible to discuss to what extent the increased use of combinations might be a transitional phenomenon related to different phases in RES-E policy support. In some countries, we can already now see a decline in certain combinations, such as in the Slovak Republic, where FIT and FIP were implemented in parallel for a period, before the FIT scheme was discontinued to the benefit of the FIP scheme.

The reason for transitioning from FIT to FIP schemes could lie in market integration issues. The higher the deployment of RES-E in terms of market share, the more important integration of RESE becomes. Not all policy types are equally capable of integrating RES-E into the overall market. Fixed FIT schemes tend to route RES-E directly from the producer to the consumer, parallel to the 
market. In this case, producers of RES-E are not market participants and cannot directly respond to market signals, e.g. negative prices in case of over-supply. FIP schemes typically integrate RES-E fully into the market, so that producers of RES-E can respond to market signals. On the other hand, Ragwitz et al. (2007) show that FIP tend to have higher remuneration levels than FIT in order to compensate for the higher risk connected with the exposure to market prices (p.117). Market integration could thus be one underlying driver of the changes observed in the application of policy supports in Europe, and could account for the increasing use of FIP and target-price FIT.

In addition to the trends observed in the historical analysis, certain new developments, which will also have an influence on the development of national RES-E supports, are expected to become apparent in the near future. Two of them are described in the following section.

\subsection{Future Trend 1 - Coordination of renewable support between countries}

Assuming that all EU member states meet their renewable targets by 2020 , and develop according to the paths laid out in their NREAPs, ten countries will have an RES-E share of more than $50 \%$, while more than half of the European countries will have a RES-E share of $35 \%$ or more (based on data from Beurskens and Hekkenberg, 2011; ECN, 2011). Achieving these deployment shares will require significant efforts to integrate the renewable electricity into the system.

As mentioned in the introduction, the European Commission has claimed that this integration will require the coordination of support across European countries. For this purpose, Directive 2009/28/EC introduces three options for EU member states to cooperate in reaching their renewable targets. By making use of cooperation mechanisms, countries become more flexible in terms of how to reach their national targets.

The cooperation options introduced by the EC directive are (see Klessmann et al., 2010, p.4):

1. Statistical transfers, where renewable production is ex-post transferred from one country's statistics to another's, based on negotiated conditions,

2. Joint projects, where countries jointly set framework conditions for projects; this may include that one country provides support payments to a project in another country, and

3. Joint support schemes, where countries define a joint support and then use e.g. statistical transfers to allocate the renewable production among themselves.

Six EU countries have integrated the use of cooperation mechanisms into their NREAPs on a quantitative basis (ECN, 2011). In total, the expected cross-border trade accounts for the very limited amount of ca. $0.4 \%$ of the expected EU renewables production in 2020 (ECN, 2011).

Nevertheless, cooperation activities could become the next trend in the development of European renewable support. Several cooperation activities, especially in form of regional concepts have so far been announced. One example of ongoing cooperation is Italy, which imports RES-E from Serbia and therewith covers part of its renewable production target with that imported electricity. Norway and Sweden have jointly established a common certificate market and have implemented it in January 2012 (Ministry of Petroleum and Energy, 2010).

When cooperating on joint projects and joint support schemes, policy makers must coordinate their decisions and, in case of joint support schemes, also agree on a common policy type to be applied in the scheme, even if it is limited to certain technologies or areas. The need for agreement will in the nature of the case lead to further convergence of RES-E supports in Europe. The potential of cooperation options in relation to the effect on a convergence of national RES-E policy supports remains to be analysed. Assessing the related benefits, potential impacts and barriers on the national and international levels will be key for contributing valuably to the discussion.

\subsection{Future Trend 2 - Country independent renewable support}

Country-independent supplementary instruments are coming increasingly into focus. The more 'traditional' instruments such as investment grants and other non-repayable assistance are already broadly applied on European basis. Financial engineering instruments are a more recent phenomenon. Both are applied mostly independently from the national support system.

Most European initiatives are implemented through the European Investment Fund (EIF), which is part of the European Investment Bank (EIB). The following paragraph is based on information the EIF provides on its own website (EIF, 2012) and on de Jager et al. (2011, p. 57-78). The EU-wide initiatives are typically designed for specific areas such as small and medium enterprises (SME) or urban development and are therewith not restricted to renewables support. The EIF/EIB provides practically all of the financial engineering instruments which are described in section 2 . Their services range from venture capital investments (since 1997) to credit enhancement (since ca. 2007). The services are mostly financed through Programmes from the European Commission, for example within the Entrepreneurship and Innovation Programme reaching from 2007 to 2013, which includes a facility for equity investment (High growth and innovative SME Facility) and a facility for loan guarantees (SMEG). The most prominent examples for 'novel' EIF support are the JEREMIE and JESSICA programmes, financed as part of the European Structural Funds. Investors in renewable projects can be supported by equity and loan investments through revolving holding funds and by different guarantees.

The support provided by the EIF/EIB is country-independent in the sense that projects are supported independently from the national support scheme. It is not country-independent from a regulatory perspective, as each EU member state has to allow the EIB to act on its territory and/or has to allocate respective funds from the national budget, e.g. a share of the Structural Funds.

Financial engineering is a new area for renewable support and it is promoted by the European Union. In February 2011, the European Commission has published a Guidance Note on Financial Engineering Instruments (European Commission, 2011d) that supports the EU member states in the implementation and the use of financial engineering instruments. Therefore it is most probable that the further developments of the national support schemes in this area will be orientated towards the European guidelines and will develop in a similar direction. 


\section{CONCLUSIONS}

This study has shown that there are indications for a bottom-up convergence of the choices of policy-makers regarding the types of policy to use and for which scope to implement them for supporting RES-E in the EU. National policy-makers are continuously implementing, changing and improving their support for RES-E in their country - and in that process, most national policy supports become increasingly similar.

By undertaking an analysis of the type of RES-E supports implemented in each country of the EU for the years 2000 to 2011, several trends have been identified and discussed. The major developments observed are:

Firstly, all European countries have established at least one and on average even three support instruments for RES-E. The dominating support instruments are feed-in tariffs as major support scheme and investment grants as supplementary support scheme.

Secondly, the type of support becomes more tailored to the installation sizes. Smaller installations are significantly more often supported with feed-in tariff schemes than larger ones. The technology type is in this regard not a significant factor.

Thirdly, the policy instruments are used more in combinations with each other ('stacking' of policy instruments). Not only are major instruments combined with more supplementary instruments, also major support instruments are implemented in parallel. The dominant trend is combining FIT and FIP schemes. More recently, also TGC schemes are being combined with FIT. The trend of utilising multiple policy instruments at once could become an important development, as this increased flexibility of policy makers to apply multiple and differentiated policy instruments will be of advantage for further cross-border cooperation.

Potential driving factors for the observed trends have been discussed, such as the increased need for market integration and transitional processes. Two expected future trends have been introduced, namely the cooperation of countries on RES-E supports, possibly leading to first implementation of regional concepts in the near future, and the emergence of country-independent supports, especially in the area of financial engineering instruments.

Also outlier-countries have been discussed that diverge from the trends to apply price-control support (such as Sweden and Poland) and to 'stack' and differentiate instruments (such as Ireland and Germany). Certain approaches seem to be persistent in some countries. It remains to be seen if these countries will follow some of the common trends in the future or if the convergence will only be partial. However, the results of the analysis suggest that for a large majority of the European countries, decisions on the types of policy to use and on the scope for which to implement them are slowly being more and more aligned even without direct policy intervention from European level. With that development continuing, an EUdriven 'top-down' harmonisation of support might become either dispensable or at least less controversial.

It is an interesting fact that at the same time as this bottom-up development is ongoing, the European Commission seems to have become more flexible in the discussion of national RES-E supports rather than a 'top-down' harmonisation, therewith opening up the room for a 'best practice' to evolve. One can expect that each of the two developments is influenced by the other.

There is certain reason to expect a further development into the direction of a bottom-up convergence of RES-E policy supports, amongst others because of new developments arising from cooperation mechanisms and new country-independent financing support in the European Union. Regional support concepts, where countries join up and establish common RES-E support schemes are expected to become a significant driving force towards more harmonised RES-E support in Europe.

\section{ACKNOWLEDGEMENT}

The authors thank Mikael Skou Anderson for valuable comments on an earlier version of this paper. This study is undertaken as part of the ENSYMORA project (www.ensymora.dk) with gratefully acknowledged funding by the Danish Strategic Research Program.

\section{APPENDIX: SUPPLEMENTARY MATERIAL}

Overview of RES-E policy types applied in the EU 27 countries in the years 2000, 2005, 2010 and 2011, differentiated for technologies.

\section{REFERENCES}

Beurskens,L.W.M., Hekkenberg,M., 2011. Renewable Energy Projections as Published in the National Renewable Energy Action Plans of the European Member States, Covering all 27 EU Member States. 28 November 2011, ECN/European Environment Agency.

BMU, 2011. RES Legal - Legal sources on the generation of electricity from renewable energy sources. Federal Ministry for the Environment, Nature Conservation and Nuclear Safety. www.res-legal.de

Couture,T., Cory,K., Kreycik,C., Williams,E., 2010. A Policymakter's Guide to Feed-in Tariff Policy Design. NREL National Renewable Energy Laboratory of the U.S. Department of Energy. Www.nrel.gov/ docs/fy10osti/44849.pdf(accessed:18July2012).

Couture,T., Gagnon,Y., 2010. An analysis of feed-in tariff remuneration models: Implications for renewable energy investment. Energy Policy 38 (2), 955-965.

Department of Energy \& Climate Change, 2012, Information on the Electricity Market Reform, United Kingdom,www.decc.gov .uk/en/ content/cms/meeting/_energy/markets/electricity/ electricity.aspx (accessed:18July2012).

de Jager,D., Klessmann,C., Stricker,E., Winkel,T., de Visser,E., Koper,M., Ragwitz,M., Held,A., Resch,G., Busch,S., Panzer,C., Gazzo,A., Roulleau,T., Gousseland,P., Henriet,M., Bouillé,A., 2011. Financing Renewable Energy in the European Energy Market. By order of the European Commission, DG Energy, TREN/D1/518-2008. Ecofys, Utrecht.

de Jager,D., Rathmann,M., 2008. Policy instrument design toreduce financing costs in renewable energy technology projects, ANNEXES. By the order of IEA Implementing Agreement on Renewable Energy Technology Development RETD. Ecofys, Utrecht.

Directive 2009/28/EC of the European Parliament and of the Council of 23 April 2009 on the Promotion of the Use of Energy from Renewable Sources and Amending and Subsequently Repealing Directives 2001/77/EC and 2003/30/EC. Official Journal of the European Union, 5.6.2009. 
ECN, 2011. Renewable Energy Projections as Published in the National Renewable Energy Action Plans of the European Member States - Database. ECN/European Environment Agency, Petten. www.ecn.nl/ nreap/(accessed December 2011).

EIF, 2012. European Investment Fund - What we do. Www.eif.org (accessed January 2012).

European Commission, 2011a. National Renewable Energy Action Plans, submitted by EU Member States in line with EC Directive 2009/28/EC. http://ec.europa.eu/energy/renewables/ action_plan_en.htm(accessed May2011).

European Commission, 2011b. Communication from the Commission to the European Parliament and the Council. Renewable Energy: Progressing towards the 2020 target, EC COM 131 final. Brussels.

European Commission, 2011c. 2009-2010 Report on progress in creating the internal and electricity market, Commission Staff Working Document. European Commission, Brussels, 9 June 2011.

European Commission, 2011d. Guidance Note on Financial Engineering Instruments under Article 44 of Council Regulation (EC No 1083/2006). DG Regional Policy, COCOF 10-0014-04-EN, 21.02.2011.

European Commission, 2006. Commission Regulation (EC No1828/2006) of 8 December 2006, setting out rules for the implementation of Council Regulation (EC No1083/2006) laying down general provisions on the European Regional Development Fund, the European Social Fund and the Cohesion Fund and of Regulation (EC No1080/2006) of the European Parliament and of the Council on the European Regional Development Fund. Official Journal of the European Union, 27.12.2006.

European Commission, 1997. Communication from the Commission. Energy for the future: Renewable sources of energy. White Paper for a Community Strategy and Action Plan. COM 97599 final, 26.11.1997.

European Communities, 2001. Community guidelines on State aid for environmental protection. 2001/C37/03. Official Journal of the European Communities, 3.2.2001.

Haas,R., Panzer,C., Resch,G., Ragwitz,M., Reece,G., Held,A., 2011. A historical review of promotion strategies for electricity from renewable energy sources in EU countries. Renewable and Sustainable Energy Reviews 15 (2), 1003-1034

Held,A., Ragwitz,M., Merkel,E., Rathmann,M., Klessmann,C., 2010. ReShaping: Shaping an Effective and Efficient European Renewable Energy Market. Indicators Assessing the Performance of Renewable Energy Support Policies in 27 Member States, EIE/08/517/SI2.529243. Fraunhofer ISI, Karlsruhe. Www.reshaping-res-policy.eu/ downloads/RE-Shaping\%20D5D6_Report_final.pdf (accessed January 2012).

Jacobsson,S., Bergek,A., Finon,D., Lauber,V., Mitchell,C., Toke,D., Verbruggen,A., 2009. EU renewable energy support policy: faith or facts? Energy Policy 37 (6), 2143-2146.

Klessmann,C., Lamers,P., Ragwitz,M., Resch,G., 2010. Re-Shaping: Shaping an Effective and Efficient European Renewable Energy Market. Design options for cooperation mechanisms between Member States and the new European Renewable Energy Directive, EIE/08/517/SI2.529243. Fraunhofer ISI,Karlsruhe. Www. reshaping-res-policy.eu/(accessed January2012).

Klessmann,C., Held,A., Rathmann,M., Ragwitz,M., 2011. Status and perspectives of renewable energy policy and deployment in the European Union-What is needed to reach the 2020 targets? Energy Policy 33 (12), 7637-7657.
Menanteau,P., Finon,D., Lamy,M., 2003. Prices versus quantities: choosing policies for promoting the development of renewable energy. Energy Policy 31(8), 799-812.

Ministry of Petroleum and Energy, 2010. Norway and Sweden agree on a common market for green certificates. Press Release No.117/10, 08.12.2010

Mitchell,C., Bauknecht,D., Connor,P.M., 2006. Effectiveness through risk reduction: a comparison of the renewable obligation in England and Wales and the feed-in system in Germany. Energy Policy 34 (3), 297-305.

Morthorst,P.E., 2003. National environmental targets and international emission reduction instruments. Energy Policy 31 (1),73-83.

Morthorst,P.E., 2000. The development of a green certificate market. Energy Policy 28 (15), 1085-1094.

Ragwitz,M., Resch,G., Busch,S., Rudolf,F., Rosende,D., Held,A., Schubert,G., 2011a. REPAP2020: Renewable Energy Policy Action Paving the Way towards 2020. Assessment of National Renewable Energy Action Plans (interim status), March 2011 http://www. repap2020.eu/55.0.html (accessed January2012).

Ragwitz,M., Held,A., Breitschopf,B., Rathmann,M., Klessmann,C., Resch,G., Panzer,C., Busch,S., Neuhoff,K., Junginger,M., Hoefnagels,R., Cusumano,N., Lorenzoni,A., Burgers,J., Boots,M., Konstantinaviciute,I., Weöres,B., 2011b. Re-Shaping: Shaping an Effective and Efficient European Renewable Energy Market. Review report on support schemes for renewable electricity and heating in Europe, EIE/08/517/SI2.529243. Fraunhofer ISI, Karlsruhe. http: //www.reshaping-res-policy .eu/ downloads /D8\%20Review\%20Report_final\%20 (RE-Shaping) .pdf (accessed January 2012).

Ragwitz,M., Held,A., Resch,G., Faber,T., Haas,R., Huber,C., Coenraads,R., Voogt,M., Reece,G., Morthorst,P.E., Grenaa Jensen,S., Konstantinaviciute,I., Heyder,B., 2007. OPTRES: Assessment and optimisation of renewable energy support schemes in the European electricity market. Final report. Fraunhofer ISI, Karlsruhe.

Ragwitz,M., Schleich,J., Huber,C., Resch,G., Faber,T., Voogt,M., Coenraads,R., Cleijne,H., Bodo,P., 2005. FORRES 2020: Analysis of the renewable energy sources' evolution up to 2020. Final Report, TREN/D2/10-2002. Karlsruhe.

Rowlands,I.H., 2005. The European directive on renewable electricity: conflicts and compromises. Energy Policy 33 (8), 965-974.

Winkel,T., Rathmann,M., Ragwitz,M., Steinhilber,S., Winkler,J., Resch,G., Panzer,C., Busch,S., Konstantinaviciute,I., 2011. Renewable Energy Policy Country Profiles. 2011 version. Based on policy information available in November 2011. Prepared within the Intelligent Energy Europe project RE-SHAPING, EIE/08/517/SI2.529243. WWw . reshaping-res-policy.eu/(accessed January 2012). 
APPENDIX. Supplementary material to: Kitzing et al. (2012), Renewable energy policies in Europe: Converging or Diverging?

\begin{tabular}{|c|c|c|c|c|c|c|c|c|c|c|c|c|c|c|c|c|c|c|c|c|c|c|}
\hline \multirow{2}{*}{$\begin{array}{l}\text { EU Member } \\
\text { State }\end{array}$} & \multirow{2}{*}{$\begin{array}{c}\text { First } \\
\text { explicit } \\
\text { RES-E } \\
\text { support * }\end{array}$} & \multirow{2}{*}{\begin{tabular}{|c|} 
Major support \\
instruments before 2000
\end{tabular}} & \multicolumn{5}{|c|}{$\begin{array}{l}\text { Major support instruments } \\
\text { in } 2000 \\
\end{array}$} & \multicolumn{5}{|c|}{$\begin{array}{l}\text { Major support instruments } \\
\text { in } 2005 \\
\end{array}$} & \multicolumn{5}{|c|}{$\begin{array}{l}\text { Major support instruments } \\
\text { in } 2010 \\
\end{array}$} & \multicolumn{5}{|c|}{$\begin{array}{l}\text { Major support instruments } \\
\text { in } 2011\end{array}$} \\
\hline & & & $\begin{array}{l}\text { Wind } \\
\text { offsh. }\end{array}$ & $\begin{array}{l}\text { Wind } \\
\text { onsh. }\end{array}$ & $\begin{array}{c}\text { Bio- } \\
\text { mass }\end{array}$ & PV & Other & $\begin{array}{l}\text { Wind } \\
\text { offsh. }\end{array}$ & $\begin{array}{l}\text { Wind } \\
\text { onsh. }\end{array}$ & $\begin{array}{c}\text { Bio- } \\
\text { mass }\end{array}$ & PV & Other & \begin{tabular}{|l|} 
Wind \\
offsh.
\end{tabular} & $\begin{array}{l}\text { Wind } \\
\text { onsh. }\end{array}$ & $\begin{array}{l}\text { Bio- } \\
\text { mass }\end{array}$ & PV & Other & $\begin{array}{l}\text { Wind } \\
\text { offsh. }\end{array}$ & $\begin{array}{l}\text { Wind } \\
\text { onsh. }\end{array}$ & $\begin{array}{l}\text { Bio- } \\
\text { mass }\end{array}$ & PV & Other \\
\hline 1 Denmark & 1979 & $\begin{array}{l}\text { 1979-: INV, wind, biogas } \\
\text { 1992-99: FIT, wind, } \\
\text { biomass }\end{array}$ & FIT & FIT & FIT & FIT & FIT & $\begin{array}{l}\text { TND(L) } \\
\text { FIP }\end{array}$ & FIP & $\begin{array}{l}\text { FIP } \\
\text { FIT }\end{array}$ & FIT & FIT & $\begin{array}{c}\text { TND(L) } \\
\text { FIP }\end{array}$ & FIP & $\begin{array}{l}\text { FIP } \\
\text { FIT }\end{array}$ & FIT & FIT & $\begin{array}{c}\text { TND(L) } \\
\text { FIP }\end{array}$ & FIP & $\begin{array}{l}\text { FIP } \\
\text { FIT }\end{array}$ & FIT & FIT \\
\hline 2 Portugal & 1988 & 1988: FIT, all techn. & - & FIT & FIT & FIT & FIT & FIT & FIT & FIT & FIT & FIT & $\begin{array}{l}\text { TND } \\
\text { FIT }\end{array}$ & $\begin{array}{l}\text { TND } \\
\text { FIT }\end{array}$ & $\begin{array}{l}\text { TND } \\
\text { FIT }\end{array}$ & $\begin{array}{l}\text { TND } \\
\text { FIT }\end{array}$ & FIT & $\begin{array}{l}\text { TND } \\
\text { FIT }\end{array}$ & $\begin{array}{l}\text { TND } \\
\text { FIT }\end{array}$ & $\begin{array}{l}\text { TND } \\
\text { FIT }\end{array}$ & $\begin{array}{l}\text { TND } \\
\text { FIT }\end{array}$ & FIT \\
\hline 3 Germany & 1989 & $\begin{array}{l}\text { 1989-96 (91-93): INV+FIT, } \\
\text { wind (PV) } \\
\text { from 1990: FIT, all techn. }\end{array}$ & - & FIT & FIT & FIT & FIT & FIT & FIT & FIT & FIT & FIT & FIT & FIT & FIT & FIT & FIT & FIT & FIT & FIT & FIT & FIT \\
\hline $4 \begin{array}{l}\text { United } \\
\text { Kingdom }\end{array}$ & $1989 / 90$ & \begin{tabular}{|l|} 
1990-98: TND, select. \\
techn via the Non-fossil fuel \\
obligation (NFFO)
\end{tabular} & - & & transitio & on phase & & TGC & TGC & TGC & TGC & TGC & $\begin{array}{l}\text { TGC } \\
\text { Band }\end{array}$ & $\begin{array}{l}\text { TGC } \\
\text { Band } \\
\text { FIT(S) }\end{array}$ & $\begin{array}{l}\text { TGC } \\
\text { Band } \\
\text { FIT(S) }\end{array}$ & $\begin{array}{c}\text { TGC } \\
\text { Band } \\
\text { FIT(S) }\end{array}$ & $\begin{array}{c}\text { TGC } \\
\text { Band } \\
\text { FIT(S) } \\
\end{array}$ & $\begin{array}{l}\text { TGC } \\
\text { Band }\end{array}$ & $\begin{array}{l}\text { TGC } \\
\text { Band } \\
\text { FIT(S) }\end{array}$ & $\begin{array}{l}\text { TGC } \\
\text { Band } \\
\text { FIT(S) }\end{array}$ & $\begin{array}{l}\text { TGC } \\
\text { Band } \\
\text { FIT(S) }\end{array}$ & $\begin{array}{l}\text { TGC } \\
\text { Band } \\
\text { FIT(S) }\end{array}$ \\
\hline 5 Italy & 1992 & 1992-97: FIT, all techn. & - & - & INV & - & - & TGC & TGC & TGC & TGC & TGC & $\begin{array}{l}\text { TGC } \\
\text { Band }\end{array}$ & $\begin{array}{l}\text { TGC } \\
\text { Band } \\
\text { FIT(S) }\end{array}$ & $\begin{array}{l}\text { TGC } \\
\text { Band } \\
\text { FIT(S) }\end{array}$ & FIP & $\begin{array}{c}\text { TGC } \\
\text { Band } \\
\text { FIT(S) } \\
\end{array}$ & $\begin{array}{l}\text { TGC } \\
\text { Band }\end{array}$ & $\begin{array}{l}\text { TGC } \\
\text { Band } \\
\text { FIT(S) }\end{array}$ & $\begin{array}{l}\text { TGC } \\
\text { Band } \\
\text { FIT(S) }\end{array}$ & FIP & $\begin{array}{l}\text { TGC } \\
\text { Band } \\
\text { FIT(S) }\end{array}$ \\
\hline 6 Belgium & 1992 & $\begin{array}{l}\text { 1992-: TAX, } \\
\text { 1997-98: FIT }\end{array}$ & - & & TAX & & & TGC & TGC & TGC & TGC & TGC & TGC & TGC & TGC & TGC & TGC & TGC & TGC & TGC & TGC & TGC \\
\hline 7 Austria & 1992 & 1992-94: INV + FIT, PV & $\mathrm{n} / \mathrm{a}$ & & TGC & & & $n / a$ & FIT & FIT & FIT & FIT & $\mathrm{n} / \mathrm{a}$ & FIT & FIT & FIT & FIT & $\mathrm{n} / \mathrm{a}$ & FIT & FIT & FIT & FIT \\
\hline 8 Sweden & 1994 & $\begin{array}{l}\text { 1994: TAX, all. techn., } \\
\text { 1994-2009: TAX, envir. } \\
\text { bonus wind }\end{array}$ & - & $\begin{array}{c}\text { TAX } \\
\text { FIT(S) } \\
\end{array}$ & $\begin{array}{c}\text { TAX } \\
\text { FIT(S) } \\
\end{array}$ & $\begin{array}{c}\text { TAX } \\
\text { FIT(S) } \\
\end{array}$ & $\begin{array}{l}\text { TAX } \\
\text { FIT(S) } \\
\end{array}$ & - & TGC & TGC & TGC & TGC & TGC & TGC & TGC & TGC & TGC & TGC & TGC & TGC & TGC & TGC \\
\hline 9 Greece & 1994 & 1994-: InvGr, all techn. & - & FIT & FIT & FIT & FIT & FIT & FIT & FIT & FIT & FIT & - & FIT & FIT & $\begin{array}{l}\text { TND(L) } \\
\text { FIT(S) }\end{array}$ & $\mathrm{FIT}$ & - & FIT & FIT & $\begin{array}{l}\text { TND(L) } \\
\text { FIT(S) }\end{array}$ & FIT \\
\hline 10 Ireland & 1994 & $\begin{array}{l}\text { 1994-2003: TND, focus on } \\
\text { wind }\end{array}$ & - & TND & TND & TAX & TAX & TAX & TAX & TAX & TAX & TAX & FIT & FIT & FIT & - & FIT & FIT & FIT & FIT & - & FIT \\
\hline $\begin{array}{c}11 \begin{array}{l}\text { Luxem- } \\
\text { bourg }\end{array} \\
\end{array}$ & 1994 & 1994-: FIT & $\mathrm{n} / \mathrm{a}$ & FIT & FIT(S) & $\mathrm{FIT}(\mathrm{S})$ & FIT(S) & $\mathrm{n} / \mathrm{a}$ & FIT & FIT(S) & $\mathrm{FIT}(\mathrm{S})$ & $\mathrm{FIT}(\mathrm{S})$ & $\mathrm{n} / \mathrm{a}$ & FIT & FIT(S) & $\mathrm{FIT}(\mathrm{S})$ & FIT(S) & $\mathrm{n} / \mathrm{a}$ & FIT & FIT(S) & FIT(S) & FIT(S) \\
\hline $\begin{array}{l}\text { Nether- } \\
\text { lands }\end{array}$ & 1994 & $\begin{array}{l}\text { 1994-: TAX } \\
\text { 1995-: FIN (low interest } \\
\text { loans) }\end{array}$ & - & $\begin{array}{l}\text { TAX } \\
\text { INV }\end{array}$ & $\begin{array}{l}\text { TAX } \\
\text { INV }\end{array}$ & $\begin{array}{l}\text { TAX } \\
\text { INV }\end{array}$ & $\begin{array}{l}\text { TAX } \\
\text { INV }\end{array}$ & FIT & FIT & FIT & FIT & $\mathrm{FIT}$ & $\mathrm{TND}(\mathrm{L})$ & FIT & FIT & FIT & FIT & TND(L) & FIT & FIT & FIT & FIT \\
\hline 13 France & 1995 & $\begin{array}{l}\text { 1995: INV: PV, hydro, wind } \\
\text { 1996: TND wind }\end{array}$ & - & $\operatorname{TND}(L)$ & INV & INV & INV & - & TND & TND & TND & TND & - & FIT & $\operatorname{TND}(\mathrm{L})$ & ) $\operatorname{TND}(\mathrm{L})$ & ) $\operatorname{TND}(\mathrm{L})$ & $\operatorname{TND}(\mathrm{L})$ & FIT & $\operatorname{TND}(\mathrm{L})$ & ) $\operatorname{TND}(\mathrm{L})$ & ) $\operatorname{TND}(\mathrm{L})$ \\
\hline & & 1996: TND wind & & (2) & INo & "No & (1) & & FIT & FIT(S) & FIT(S) & $\mathrm{FIT}(\mathrm{S})$ & FIT & . & $\mathrm{FIT}(\mathrm{S})$ & $\mathrm{FIT}(\mathrm{S})$ & FIT(S) & FIT & HII & FIT(S) & FIT(S) & $\mathrm{FIT}(\mathrm{S})$ \\
\hline 14 Spain & 1997 & $\begin{array}{l}\text { (from } 1980 \text { large } \\
\text { hydropower) 1997-2004: } \\
\text { FIT, all techn. }\end{array}$ & - & FIT & FIT & FIT & FIT & - & $\begin{array}{l}\text { FIP } \\
\text { FIT }\end{array}$ & $\begin{array}{l}\text { FIP } \\
\text { FIT }\end{array}$ & $\begin{array}{l}\text { FIP } \\
\text { FIT }\end{array}$ & $\begin{array}{l}\text { FIP } \\
\text { FIT }\end{array}$ & $\begin{array}{l}\text { FIP } \\
\text { FIT }\end{array}$ & $\begin{array}{l}\text { FIP } \\
\text { FIT }\end{array}$ & $\begin{array}{l}\text { FIP } \\
\text { FIT }\end{array}$ & FIT & $\begin{array}{l}\text { FIP } \\
\text { FIT }\end{array}$ & $\begin{array}{l}\text { FIP } \\
\text { FIT }\end{array}$ & $\begin{array}{l}\text { FIP } \\
\text { FIT }\end{array}$ & $\begin{array}{l}\text { FIP } \\
\text { FIT }\end{array}$ & FIT & $\begin{array}{l}\text { FIP } \\
\text { FIT }\end{array}$ \\
\hline 15 Finland & 1997 & 1997-: TAX & TAX & TAX & TAX & - & - & TAX & TAX & TAX & TAX & TAX & TAX & TAX & $\begin{array}{l}\text { TAX } \\
\text { FIT } \\
\end{array}$ & - & TAX & FIT & FIT & FIT & - & FIT \\
\hline 16 Latvia & 2002 & & $2002-0$ & 3: FIT, wi & ind solar, & , biomass & & - & & transitio & on phase & & FIT & FIT & FIT & FIT & FIT & FIT & FIT & FIT & FIT & FIT \\
\hline 17 Lithuania & 2002 & & & & & & & FIT & FIT & FIT & FIT & FIT & FIT & FIT & FIT & FIT & FIT & FIT & FIT & FIT & FIT & FIT \\
\hline 18 Estonia & 2003 & & & & & & & - & FIT & FIT & FIT & FIT & $\begin{array}{c}\text { FIP(S) } \\
\text { FIT }\end{array}$ & $\begin{array}{l}\text { FIP } \\
\text { FIT }\end{array}$ & $\begin{array}{c}\mathrm{FIP}(\mathrm{S}) \\
\mathrm{FIT}\end{array}$ & $\begin{array}{l}\text { FIP } \\
\text { FIT }\end{array}$ & $\begin{array}{l}\text { FIP } \\
\text { FIT }\end{array}$ & FIP(S) & FIP & $\mathrm{FIP}(\mathrm{S})$ & FIP & FIP \\
\hline 19 Hungary & 2003 & & & & & & & $n / a$ & FIT & FIT & FIT & FIT & $\mathrm{n} / \mathrm{a}$ & $\begin{array}{l}\text { TND } \\
\text { FIT(S) }\end{array}$ & $\mathrm{FIT}(\mathrm{S})$ & FIT & FIT & $\mathrm{n} / \mathrm{a}$ & $\mathrm{FIT}(\mathrm{S})$ & FIT(S) & FIT & FIT \\
\hline 20 Malta & 2004 & & & & & & & - & $\operatorname{INV}(\mathrm{S})$ & - & $\begin{array}{l}\mathrm{FIT}(\mathrm{S}) \\
\operatorname{INV}(\mathrm{S})\end{array}$ & - & - & $\operatorname{INV}(\mathrm{S})$ & - & $\begin{array}{l}\text { FIT(S) } \\
\operatorname{INV}(S)\end{array}$ & ) & - & $\operatorname{INV}(\mathrm{S})$ & - & $\begin{array}{l}\text { FIT(S) } \\
\operatorname{INV}(\mathrm{S})\end{array}$ & ) \\
\hline 21 Cyprus & 2004 & & & & & & & - & INV & INV & INV & INV & FIT & FIT & FIT & FIT & FIT & FIT & FIT & FIT & FIT & FIT \\
\hline 22 Slovenia & 2004 & & & & & & & $n / a$ & $\begin{array}{c}\text { FIP } \\
\text { FIT(S) }\end{array}$ & $\begin{array}{c}\text { FIP } \\
\text { FIT(S) }\end{array}$ & $\begin{array}{c}\text { FIP } \\
\text { FIT(S) }\end{array}$ & $\begin{array}{c}\text { FIP } \\
\text { FIT(S) }\end{array}$ & $\mathrm{n} / \mathrm{a}$ & $\begin{array}{l}\text { FIP } \\
\text { FIT(S) }\end{array}$ & $\begin{array}{c}\text { FIP } \\
\text { FIT(S) }\end{array}$ & $\begin{array}{l}\text { FIP } \\
\text { FIT(S) }\end{array}$ & $\begin{array}{c}\text { FIP } \\
\text { FIT(S) }\end{array}$ & $n / a$ & $\begin{array}{c}\text { FIP } \\
\text { FIT(S) }\end{array}$ & $\begin{array}{l}\text { FIP } \\
\text { FIT(S) }\end{array}$ & $\begin{array}{l}\text { FIP } \\
\text { FIT(S) }\end{array}$ & $\begin{array}{c}\text { FIP } \\
F I T(S)\end{array}$ \\
\hline \begin{tabular}{|l}
$23 \begin{array}{l}\text { Slovak } \\
\text { Republic }\end{array}$ \\
\end{tabular} & 2005 & & & & & & & $n / a$ & FIT & FIT & FIT & FIT & $\mathrm{n} / \mathrm{a}$ & $\begin{array}{l}\text { FIP } \\
\text { FIT }\end{array}$ & $\begin{array}{c}\mathrm{FIP}(\mathrm{S}) \\
\mathrm{FIT}\end{array}$ & $\begin{array}{l}\text { FIP } \\
\text { FIT }\end{array}$ & $\begin{array}{c}\mathrm{FIP}(\mathrm{S}) \\
\mathrm{FIT}\end{array}$ & $\mathrm{n} / \mathrm{a}$ & $\begin{array}{l}\text { on } \\
\text { hold }\end{array}$ & $\mathrm{FIP}(\mathrm{S})$ & $\begin{array}{l}\text { on } \\
\text { hold }\end{array}$ & $\mathrm{FIP}(\mathrm{S})$ \\
\hline 24 Romania & 2005 & & & & & & & $n / a$ & $\begin{array}{l}\text { TGC } \\
\text { Band }\end{array}$ & $\begin{array}{l}\text { TGC } \\
\text { Band }\end{array}$ & $\begin{array}{l}\text { TGC } \\
\text { Band }\end{array}$ & $\begin{array}{l}\text { TGC } \\
\text { Band }\end{array}$ & $\mathrm{n} / \mathrm{a}$ & $\begin{array}{l}\text { TGC } \\
\text { Band }\end{array}$ & $\begin{array}{l}\text { TGC } \\
\text { Band }\end{array}$ & $\begin{array}{l}\text { TGC } \\
\text { Band }\end{array}$ & $\begin{array}{l}\text { TGC } \\
\text { Band }\end{array}$ & $\mathrm{n} / \mathrm{a}$ & $\begin{array}{l}\text { TGC } \\
\text { Band }\end{array}$ & $\begin{array}{l}\text { TGC } \\
\text { Band }\end{array}$ & $\begin{array}{l}\text { TGC } \\
\text { Band }\end{array}$ & $\begin{array}{l}\text { TGC } \\
\text { Band }\end{array}$ \\
\hline 25 Poland & 2005 & & & & & & & TGC & TGC & TGC & TGC & TGC & TGC & TGC & TGC & TGC & TGC & TGC & TGC & TGC & TGC & TGC \\
\hline $26 \begin{array}{l}\text { Czech } \\
\text { Republ }\end{array}$ & $2005 / 06$ & & & & & & & $\mathrm{n} / \mathrm{a}$ & FIP & FIP & FIP & FIP & $1 / d$ & FIP & FIP & FIP & FIP & $\mathrm{n} / \mathrm{a}$ & FIP & FIP & FIP & FIP \\
\hline & & & & & & & & & FIT & FIT & FIT & FIT & & FIT & FIT & FIT & FIT & rira & FIT & FIT & FIT & FIT \\
\hline 27 Bulgaria & 2007 & & & & & & & & & & & & - & FIT & FIT & FIT & FIT & - & FIT & FIT(S) & FIT & FIT \\
\hline
\end{tabular}

Sources: BMU (2011), de Jager et al. (2011, p. 155ff), de Jager and Rathmann (2008), ECN (2011), European Commission (2011a), Haas et al. (2011), Held et al. (2010), Ragwitz et al. (2005, p. 35ff), Ragwitz et al. (2007), Ragwitz et al. (2011), Teckenburg et al. (2011)

FIT: Feed-in tariff, FIP: Feed-in Premium, FIT/P: Feed-in premium or feed-in tariff by choice, FIT(S): Feed-in tariff for small installations, typically <1MW, in some cases <5MW, in France <12MW; TGC: Tradeable Green Certificates in a quota obligation system, TND: Tenders, TND(L): Tenders for large installations, >10MW, InvGr: Investment Grant (only mentioned if substantial amount of total cost and no other instrument available), TAX: Tax incentive or tax relief (only mentioned if applied as major support instrument); Other: include wave \& tide, solar thermal, small scale hydro, geothermal, biogas

* In order to appear in the statistics, a support scheme must be decided, implemented, in force, and open for new projects in the respective year. TGC systems must have a functional trading platform. Announced schemes, schemes with a legal basis but without implementation, and schemes without sufficient budget are not considered. 